\title{
The Effect of $\gamma$-irradiation and Cooking on the Physicochemical Properties of African Oil Bean Seed (Pentaclethra macrophylla benth) and Its Oil Extract
}

\author{
V. N. Enujiugha (Corresponding author), I. O. Olotu \& S. A. Malomo \\ Department of Food Science and Technology, Federal University of Technology \\ PMB 704, Akure, Nigeria \\ Tel: 234-803-426-1870_E-mail: venujiugha@yahoo.com \\ T. A. Sanni \\ Department of Food Science and Technology \\ Joseph Ayo Babalola University, Ikeji-Arakeji, Nigeria
}

Received: February 27, 2012

Accepted: March 14, 2012 Published: May 1, 2012

doi:10.5539/jfr.v1n2p189

URL: http://dx.doi.org/10.5539/jfr.v1n2p189

\begin{abstract}
Irradiation is a potentially useful technology for ensuring the safety and extending the shelf-life of food products. The effects of $\gamma$-irradiation $(5 \mathrm{kGy}, 10 \mathrm{kGy})$, cooking and combined treatment of $10 \mathrm{kGy}$ irradiation and cooking on the chemical and functional properties of African oil bean seed (Pentaclethra macrophylla Benth) and physicochemical properties of its oil were investigated. The irradiated seeds and un-irradiated seeds were mechanically dehulled and milled into flour using an attrition mill. 'Raw seed', 'cooked seed', 'irradiated (5kGy) seed', 'irradiated (10kGy) seed' and 'irradiated (10kGy) and cooked seed' flour samples were analyzed for proximate composition, mineral content, functional properties and antinutritional factors, and the seed oils were analyzed for peroxide value, iodine value, acid value and free fatty acid content. The results show that the combined effect of $\gamma$-irradiation and cooking gave highest increase in nutritional quality, reducing protein from $32.91 \mathrm{~g} / 100 \mathrm{~g} \mathrm{DM}$ in the raw seed to $30.55 \mathrm{~g} / 100 \mathrm{~g}$ DM and increasing fat content from $47.43 \mathrm{~g} / 100 \mathrm{~g} \mathrm{DM}$ to $51.19 \mathrm{~g} / 100 \mathrm{~g}$ DM. Combined treatment led to the retention of sodium, calcium, zinc and iron more than the single treatments, but the same process reduced magnesium from $0.52 \mathrm{mg} / 100 \mathrm{~g}$ to $0.47 \mathrm{mg} / 100 \mathrm{~g}$ and phosphorus from $0.43 \mathrm{mg} / 100 \mathrm{~g}$ to $0.35 \mathrm{mg} / 100 \mathrm{~g}$. Least gelation concentration and emulsion capacity increased with combined $\gamma$-irradiation and cooking, whereas foaming capacity and water absorption capacity decreased significantly $(\mathrm{p}<0.05)$. Gamma-irradiation and cooking reduced the concentration of all the antinutritional factors. Combined $\gamma$-irradiation and cooking increased the peroxide value significantly $(\mathrm{p}<0.05)$ from $7.03 \mathrm{mg} / \mathrm{g}$ oil to $16.50 \mathrm{mg} / \mathrm{g}$ oil and increased the acid value, iodine value and free fatty acid of P. macrophylla seed oil. Combination of $\gamma$-irradiation and cooking increased nutrient bioavailability in the seed; it led to improvement in the functional properties and increased the susceptibility of the oil to rancidity.
\end{abstract}

Keywords: Gamma irradiation, Cooking, Oil bean seed, Physicochemical properties, Oil extract

\section{Introduction}

The ionizing radiation of the electromagnetic spectrum is the radiation of primary interest in food preservation, and comprises of gamma ray, X-ray and rays from high energy electron beams. Irradiation can be used as a method for preserving many types of food. The principal process which involves the use of gamma irradiation involves exposing the food to a specific dose of ionizing radiation for example, cobalt 60 (60Co) which acts by effecting the alteration of cell structure, DNA damage etc. for the purpose of disinfestations, sprouting inhibition, achieving partial or incomplete inactivation of cells of specific pathogens or of potential spoilage microorganisms, that may naturally be present on unprocessed food and other benefits.

The method employed in food preservation via $\gamma$-irradiation is done through the use of normal radioactive decay which involves the use of radioisotopes, generally $60 \mathrm{Co}$ and caesium 137 (137Cs). It is the cheapest source of 
radiation because the source element i.e. cobalt and caesium can be obtained by atomic fission or atomic waste product. One of the most important properties of gamma ray is that it carries no mass/charge but discrete amounts (quanta) of energy. It can behave like a wave or particle (photons), has excellent penetrating power by producing large amount of energy as high as $100 \mathrm{Kev}$, and has the shortest wavelength. The major concern in fatty foods is the acceleration of oxidative rancidity. Oxidative rancidity causes the formation of hydroperoxyl radicals which gives rise to unstable hydroperoxides that form carbonyl compounds leading to rancidity in unsaturated fatty acid. Irradiation is more effective in the reduction of protease inhibitors, oligosaccharides and phytic acid and other antinutrients in legumes and cereals than other domestic and industrial processing techniques.

Some products require irradiation special conditions such as low temperature, or in an oxygen free atmosphere with combination treatments such as heat and irradiation (Farkas, 1990; Grant \& Patterson, 1995). Combined food processing is a strategy that permits effective processing while minimizing the severity of treatment. To maximize the effectiveness of combination treatment, mild irradiation treatment between 1 and $10 \mathrm{KGy}$ is stated as the best (Campbell-Platt \& Grandson, 1990). The use of cooking and $\gamma$-irradiation as forms of preservation are both proven technologies and the effectiveness of both could be maximized if they are combined.

The benefit of combining irradiation with cooking can be deduced by comparing an irradiated cooked seed and irradiated uncooked seed and also irradiated seed and irradiated cooked seed all at the same dosage level. The effect of this combined treatment method was studied in the present research work using African oil bean seed.

The African oil bean tree Pentaclethra macrophylla Benth (Leguminosae, subfamily mimosoidae) is a large leguminous, nodule-forming multipurpose tree species occurring naturally in the humid lowlands and some parts of the sub-humid zones of West and Central Africa (Enujiugha, 2008). The oil bean seed serves as a good source of edible protein and calories as the seeds are made edible by fermenting for 3-5 days. In parts of sub-Saharan Africa, the fermented product is eaten with stockfish, garden egg and sliced tapioca in a mixed vegetable salad; this is the extremely popular 'African salad', a favourite snack at masquerade and other festivals (Achinewhu, 1982). It serves as a spice and flavouring agent (Enujiugha \& Agbede , 2000). The oil content of the African oil bean seed was found to be $52.28 \%$ (Enujiugha \& Ayodele-Oni, 2003) with the following percent by weight of the different components: triglyceride, $39.9 \%$; diglyceride, $2.1 \%$; monoglyceride, $1.6 \%$; free fatty acids (FFA), $32.9 \%$; and sterol, $23.5 \%$. In the fermented seed oil, the other components with exception of sterol are hydrolyzed to the free fatty acids (triglycerides become $4.89 \%$ while free fatty acids become $73.85 \%$ ). African oil been seed is high in major mineral nutrients such as phosphorus, calcium, magnesium and sodium (Enujiugha \& Akanbi, 2002) making it perform important functions in the body when consumed. The African oil bean seed is also known to contain high concentrations of lectins (Enujiugha \& Agbede, 2000), trypsin inhibitors (Kingsley, 1995), phytates, tannins and oxalates (Enujiugha \& Ayodele-Oni, 2003). The objective of this study was to assess the effect of different $\gamma$-irradiation doses and combination treatment with cooking (hurdle technique) on the nutritional quality and functional properties of the seed and the physicochemical properties of its oil extract.

\section{Materials and Methods}

\subsection{Materials}

Freshly harvested African oil bean seeds (Pentaclethra macrophylla Benth) were obtained from local farmers in Imo State of Nigeria. Upon receipt, the oil bean seeds were visually inspected and defective seeds were discarded. The seeds were then transported to the laboratory and kept in airtight polyethylene containers in a dry and cool environment until ready for use. All the chemicals and reagents used in the study were of analytical grade

\subsection{Preparation of samples}

The African oil bean seeds were packaged in two polyethylene bags which were sealed for each treatment. Samples were then irradiated to absorbed doses of 5 and $10 \mathrm{kGy}$ using a cobalt-60 gamma irradiation source (Model GS 1000, Category 4, Panorama Wet storage Source, Siemen, Germany) located at Shedan Science and Technology Complex (SHESTCO), Abuja, Nigeria. The samples were irradiated at room temperature. Following irradiation the $5 \mathrm{kGy}$ irradiated sample was milled immediately while the $10 \mathrm{kGy}$ irradiated sample was divided into two parts, a part was milled while the other part was subjected to hydrothermal treatment. Raw and 10kGy irradiated seeds were subjected to hydrothermal treatment for 6 hours at $100^{\circ} \mathrm{C}$, dehulled, sun dried and milled into flour. The oil in each sample except the $5 \mathrm{kGy}$ irradiated sample was extracted using the Sohxtlet apparatus in order to study the effect of combined treatment on the oil quality. 


\subsection{Determination of chemical composition}

Quantitative composition was determined on each of the samples using the following analytical methods: Moisture content according to method 964.22 (AOAC, 1990); crude protein according to method 955.04 (AOAC, 1990); crude fat extracted overnight in a Soxhlet extractor with hexane and quantified gravimetrically; ash according to method 923.03 (AOAC, 1990); crude fibre determined after digesting a known weight of fat-free sample in refluxing $1.25 \%$ sulphuric acid and $1.25 \%$ sodium hydroxide; and carbohydrates determined by the difference method (subtracting the percent crude protein, crude fibre, crude fat, and ash from $100 \%$ dry matter). All analyses were carried out in triplicates. The energy contents of the samples were obtained by multiplying crude protein, crude fat and carbohydrate contents by factors of 4, 9 and 4, respectively (Enujiugha \& Ayodele-Oni, 2003).

\subsection{Mineral analysis}

Analysis of sodium and potassium contents of the samples was carried out using flame photometry (Model PFP 7, Jenway, UK), while phosphorus was determined by the phosphovanado-molybdate (yellow) colorimetric method (AOAC, 1990). The other elemental concentrations were determined, after wet digestion of sample ash with a mixture of nitric and perchloric acids $(1: 1 \mathrm{v} / \mathrm{v})$, using Atomic Absorption Spectrophotometer (AAS, Buck Model 20A, Buck Scientific, East Norwalk, CT06855, USA). All the determinations were carried out in triplicates.

\subsection{Determination of anti-nutritional factors}

The method of Wheeler and Ferrel (1971) as modified by Reddy et al. (1982) was used for phytic acid and phytate-phosphorus determinations. Phytic acid was extracted from each $3 \mathrm{~g}$ flour sample with 3\% trichloroacetic acid by shaking at room temperature followed by high-speed centrifugation (30,000 x g for $5 \mathrm{~min})$. The phytic acid in the supernatant was precipitated as ferric phytate, and iron in the sample was estimated. Phytate-phosphorus (phytate-P) was calculated from the iron results assuming a 4:6 iron: phosphorous molecular ratio according to method 970.39 (AOAC, 1990). The phytic acid was estimated by multiplying the amount of phytate-phosphorous by the factor 3.55 based on the empirical formula C6P6O24H18 (Enujiugha \& Olagundoye, 2001).

Tannin contents were determined by the modified vanillin-HCl method (Burns, 1971; Price et al., 1978). A 2.00 g sample was extracted with $50 \mathrm{ml} 99.9 \%$ methanol for $20 \mathrm{~min}$ at room temperature with constant agitation. After centrifugation for $10 \mathrm{~min}$ at $653 \mathrm{x} \mathrm{g}, 5 \mathrm{ml}$ of vanillin $-\mathrm{HCl}(2 \%$ vanillin, $1 \% \mathrm{HCl})$ reagent was added to 1 $\mathrm{ml}$ aliquots, and the colour developed after $20 \mathrm{~min}$ at room temperature was read at $500 \mathrm{~nm}$. Correction for interference from natural pigments in the sample was achieved by subjecting the extract to the conditions of the reaction, but without vanillin reagent. A standard curve was prepared using catechin (Sigma Chemical, St. Louis, $\mathrm{MO}$ ) after correcting for blank, and tannin concentration was expressed in $\mathrm{mg} / 100 \mathrm{~g}$.

Determination of oxalate was by the AOAC (1990) method. One gram $(1 \mathrm{~g})$ of finely ground sample was dissolved in $75 \mathrm{ml}$ of $1.5 \mathrm{~N} \mathrm{H}_{2} \mathrm{SO}_{4}$. The solution was carefully stirred intermittently with a magnetic stirrer for about $1 \mathrm{~h}$ and filtered using Whatman no. 1 filter paper. A $25 \mathrm{ml}$ sample of the filtrate (extract) was collected and titrated hot $\left(80-90^{\circ} \mathrm{C}\right)$ against $0.1 \mathrm{~N} \mathrm{KMnO}_{4}$ solution to the point when a faint pink colour appeared that persisted for at least 30 seconds. The concentration of oxalate in each sample was got from the calculation: $1 \mathrm{ml}$ $0.1 \mathrm{~N}$ permanganate $=0.006303 \mathrm{~g}$ oxalate. All procedures were carried out in triplicates.

\subsection{Determination of functional properties}

The determination of water and oil absorption capacities followed a modification of the method of Prinyawiwatkul et al. (1997). Each flour sample $(5.0 \mathrm{~g})$ was thoroughly mixed, without pH adjustment with 25 $\mathrm{ml}$ of deionized water or oil in 50-ml centrifuge tubes. Suspensions were stirred intermittently over a $30 \mathrm{~min}$ period at room temperature $\left(25^{\circ} \mathrm{C}\right)$ and then centrifuged at $12,000 \times \mathrm{g}$ for $30 \mathrm{~min}$ at $25^{\circ} \mathrm{C}$. The volume of decanted supernatant was measured, and the water and oil absorption capacities were then calculated. Triplicate samples were analyzed for each flour sample category.

The least gelation concentration was carried out as described by Enujiugha and Akanbi (2005). Triplicate suspensions of $1-20 \%$ seed flour sample (dry w / v, at $1 \%$ increment) were prepared in $10 \mathrm{ml}$ of deionized water and mixed thoroughly without $\mathrm{pH}$ adjustment. The slurries were heated in $125 \mathrm{x} 20 \mathrm{~mm}$ screw- capped test tubes in a water bath at $95 \pm 2{ }^{\circ} \mathrm{C}$. After $1 \mathrm{~h}$ of heating, tubes were immediately cooled in tap water for $30 \mathrm{sec}$ and then in ice water for 5 min to accelerate gel formation. All tubes were then held at $4^{\circ} \mathrm{C}$ for $3 \mathrm{~h}$. Least gelation concentration (percent) was determined as the concentration above which the sample remained in the bottom of the inverted tube. 
The foaming properties of the samples were determined using the procedure of Coffmann and Garcia (1977). Exactly $2.0 \mathrm{~g}$ of sample was weighed into $60 \mathrm{ml}$ distilled water in a $100 \mathrm{ml}$ cylinder. Solid material was dispersed with spatula and the suspension was whipped for 5 min using ultra-Turax T25 mixer at a high speed. Volumes before and after whipping were noted and volume increase due to whipping was then calculated. The volume of foam in the standing cylinder was also recorded for foam stability studies at 1, 5, 10, 20, 30, 60, 90, 120 and 180 min after whipping. The results were expressed in percentages ( $\mathrm{g} / \mathrm{g}$ basis).

Emulsifying properties were determined using a modification of the method described by Igeet al. (1984). A known quantity ( $1.8 \mathrm{~g}$ ) of sample was dispersed in $25 \mathrm{ml}$ distilled water, and $25 \mathrm{ml}$ vegetable oil (pure groundnut oil) was added. The $50 \mathrm{ml}$ mixture was emulsified at high speed using ultra-Turax T25 mixer for 1 min. Emulsion was filled into centrifuge tubes and centrifuged for $5 \mathrm{~min}$ at $1,300 \times 6 \mathrm{rpm}$. Percentage emulsion was then expressed as \% Emulsion $=100$ (height of emulsified layer) $/($ height of whole solution in centrifuge tube). The results were expressed in percentages ( $\mathrm{g} / \mathrm{g}$ basis).

\subsection{Determination of seed oil characteristics}

The seed oils of the samples were extracted using Soxhlet apparatus and the rancidity indices (peroxide value, free fatty acids content and acid value) were determined using the methods of Pearson (1976). The peroxide values were expressed as milliequivalents of peroxide oxygen per $\mathrm{kg}$ of sample $(\mathrm{mEq} / \mathrm{kg})$ while the free fatty acids were expressed as $\mathrm{g}$ oleic acid per $100 \mathrm{~g}$ of sample $(\mathrm{g} / 100 \mathrm{~g})$. The acid values were expressed as $\mathrm{mg} \mathrm{NaOH}$ per $\mathrm{g}$ of sample (mg NaOH/g). Iodine value was determined by the AOAC (1990) method using Wij's solution.

\subsection{Statistical analysis}

Data collected from the study were subjected to analysis of variance (ANOVA) as described by Steel and Torrie, (1980). Differences among means were separated using Duncan's multiple range test; significances were accepted at $5 \%$ level $(\mathrm{P} \geq 0.05)$. The statistical software used was SAS 9.0 (2008) for windows.

\section{Results and Discussion}

\subsection{Nutritional evaluation of pentaclethra macrophylla}

The quality or nutritional value of any consumable plant part including seeds depends on its basic constituents, including proteins, carbohydrates, minerals and vitamins. The results of the different treatment on the proximate composition per $100 \mathrm{~g}$ dry weight and energy value in $\mathrm{KJ}$ of Pentaclethra macrophylla seeds are shown in Table 1.

The protein content decreased from $32.91 \mathrm{~g} / 100 \mathrm{~g}$ DM in raw Pentaclethra macrophylla to $31.31 \mathrm{~g} / 100 \mathrm{~g}$ DM in cooked Pentaclethra macrophylla. This could be attributed to the leaching of protein into processing water (Kingsley, 1995). Protein content reduced to $30.55 \mathrm{~g} / 100 \mathrm{~g}$ DM when irradiation was combined with cooking. Irradiation treatment at $5 \mathrm{kGy}$ and $10 \mathrm{kGy}$ had no significant effect on protein, fat and carbohydrate content (p > 0.05). Similar findings were observed by Aziz and Mahrous (2004), who reported that there were no changes in protein, lipid or carbohydrate, contents of gamma-irradiated wheat and bean seeds at a dose level of $5 \mathrm{kGy}$. The results show that although irradiation in itself did not affect protein content, it aided the negative effects of cooking when in combination treatment.

Cooking reduced carbohydrate content from $14.54 \mathrm{~g} / \mathrm{kg}$ DM to $12.96 \mathrm{~g} / 100 \mathrm{~g}$ DM and there was no significant difference when cooking was combined with $10 \mathrm{kGy}$ irradiation. During the cooking of legume seeds, two simultaneous processes occur inside and outside the cotyledon cells, the gelatinization of intracellular starch and denaturation of proteins are accompanied by softening of the seeds as a result of plasticization or partial solubilization of the middle lamella, which leads to separation of individual cotyledon cells. Legume seeds require a relatively long cooking time, ranging from 1 to $6 \mathrm{~h}$ and it is known that starch is mainly responsible for the textural quality of cereals and legumes and especially for changes during cooking (Osman, 1967). The amount of hydrolysis is intimately related to the extent of gelatinisation, which is itself a function of the temperature of processing and the amount of water present (Tester \& Sommerville, 2000; R.F. Tester \& M.D. Sommerville, 2000; Tester \& Sommerville, 2000). Neither 0.5 kGy nor $10 \mathrm{kGy}$ doses had significant effect on total available carbohydrates, total free sugars, total starches or dextrins or on the eight individual free sugars identified in pistachio kernels (Kashani \& Valadon, 1984). Cooking increased fibre content of Pentaclethra macrophylla but the fibre content was significantly reduced when irradiation at $10 \mathrm{kGy}$ was combined with cooking. Fibre levels may be reduced in direct proportion to the level of irradiation due to depolymerisation and delignification.

It appears that radiation results in random depolymerisation and decomposition of cellulose (Jeromeet al.,1952) and seriously weakens the cellulosic fibre ( Gilfillan \& Linden, 1955). 
The moisture content of the cooked seed and irradiated cooked seed increased significantly due to absorption of the cooking water. Gamma irradiation at $5 \mathrm{kGy}$ and $10 \mathrm{kGy}$ had no effect on the moisture content. Similar findings were o observed by Rady et al., (2002) who reported that gamma irradiation has no real effect on moisture content of oil seeds.

Irradiation is also acknowledged to cause fewer overall physical and chemical changes than cooking, freezing or canning (Josephson \& Peterson, 1983; Josephson et al., 1978; Molins, 2001). Increased irradiation dose from 5 $\mathrm{kGy}$ to $10 \mathrm{kGy}$ caused fewer overall chemical changes than cooking and combined treatment of $10 \mathrm{kGy}$ and this conformed with the finding of El- Niely (1996) who found that irradiation of broad beans (Vicia faba) at levels of 2.5, 5, 10 and $20 \mathrm{kGy}$ did not induce any significant change in their chemical composition. Farag, (1989) reported that soybeans irradiated at a dose level of $10 \mathrm{kGy}$ retained their normal levels of moisture, crude protein, fat and ash. This dose level does not result in the denaturation of protein, and does not affect the nitrogen containing components of the food materials.

The fat content of Pentaclethra macrophylla increased from $47.30 \mathrm{~g} / 100 \mathrm{~g}$ DM to $50.39 \mathrm{~g} / 100 \mathrm{~g}$ DM during cooking this could be as a result of heating of the fat during cooking or the liquefaction of solid fats into oils (Carmordy \& Wrangham, 2009).

Cooking and combined treatment of $10 \mathrm{kGy}$ irradiation increased energy value as a result of the increase in fat content and calorific content. Irradiation produces so little chemical change in food that it is difficult to design a test to determine whether a food has been irradiated or not (Stevenson, 1994). However, the combination treatment was quite effective in bringing about changes in nutrient composition.

\subsection{The effect of processing on the mineral composition of pentaclethra macrophylla}

Various minerals have been shown to be essential for man. They are divided into major and trace elements. The major mineral elements are calcium, potassium, sulphur, sodium, chlorine, phosphorus and magnesium while the trace elements include iron, cobalt, manganese, copper, molybdenum, selenium, chromium, tin, zinc, nickel and fluorine. They are ingested as part of certain foods. Table 2 shows the mineral composition of the Penthaclethra macrophylla. The results of the mineral analysis indicate that the oil bean seeds are rich in potassium and calcium which are paramount for teeth and bone development. Cobalt and lead were not present. All treatment reduced the potassium content of Pentaclethra macrophylla. The decrease in potassium content in the cooked sample could be attributed to leaching during processing, especially cooking. Cooking of the oil bean seeds brought about a significant $(\mathrm{p}<0.05)$ increase in calcium from $2.61 \mathrm{mg} / 100 \mathrm{~g}$ to $3.31 \mathrm{mg} / 100 \mathrm{~g}$, zinc from $0.30 \mathrm{mg} / 100 \mathrm{~g}$ to $0.45 \mathrm{mg} / 100 \mathrm{~g}$ phosphorus from $0.43 \mathrm{mg} / 100 \mathrm{~g}$ to $0.48 \mathrm{mg} / 100 \mathrm{~g}$ and iron from $0.24 \mathrm{mg} / 100 \mathrm{~g}$ to $0.36 \mathrm{mg} / 100 \mathrm{~g}$. Similar findings were reported for C. esculenta and some vegetables where cooking caused significant increases in the levels of some mineral elements (Mephba et al., 2007). The increase in iron could be attributed to the quality of the cooking water as a result of the presence of dissolved minerals. Sodium content in Pentaclethra macrophylla was low $(0.26 \mathrm{mg} / 100 \mathrm{~g})$. Balogun and Fetuga (1980) linked the low sodium levels of some legume seeds to the subnormal concentrations of sodium in tropical crops, which are a reflection of the low sodium contents of the soils. A previous study observed an increase of calcium with processing (hydrothermal treatment and fermentation) of the Pentaclethra macrophylla seeds (Enujiugha \& Olagundoye, 2001).

Sodium, zinc, iron and phosphorus were increased by $5 \mathrm{kGy}$ irradiation but that of magnesium was not significant $(\mathrm{p}>0.05)$. Increased dose of irradiation from $5 \mathrm{kGy}$ to $10 \mathrm{kGy}$ decreased all the minerals present. Combined treatment lead to the retention of sodium calcium, zinc and iron but the same process reduced magnesium and phosphorus significantly $(\mathrm{p}<0.05)$.

The $\mathrm{K} / \mathrm{Na}$ ratio of $>1$ in $5 \mathrm{kGy}$ irradiated, 10kGy irradiated and cooked 10kGy irradiated sample might be desirable since an average human diet is low in $\mathrm{K}$ and high in Na. Combination treatment increased the ratio slightly.

All the assayed micro-minerals $(\mathrm{Zn}, \mathrm{Fe})$ were generally low in the samples; iron had the lowest concentration. Underwood (2003) has suggested that food and nutrition insecurity which affects an estimated 815 million households (the majority in developing countries) is in large part due to micronutrient deficiencies.

\subsection{Effect of processing on functional properties}

Functionality as applied to food ingredients is defined as any property on which the utility of those foods depends. A functional food may be defined as a food having health promoting benefits and/or disease preventing properties over and above its usual nutritional value. The effects of cooking, irradiation and combined treatment on the functional properties of African oil bean seeds are presented in Table 3 . 
Water and fat retention are basic functional properties of proteins which determine the quality (juiciness, texture, binding of structure, appearance and mouth feel)of oil absorption involves the physical entrapment of oil by food components and the affinity of non-polar protein side chains for lipids (Kinsella, 1976). Irradiation at the dose of $5 \mathrm{kGy}$ and $10 \mathrm{kGy}$ increased oil and water absorption capacity $(\mathrm{p}<0.05)$. The oil and water absorption capacity values obtain for cooked and irradiated (10kGy) cooked were not significantly different $(\mathrm{p}>0.05)$ from that of the raw samples. The higher oil absorption capacity values may imply that non-polar amino acid residues predominate in Pentaclethra macrophylla. Increases in oil and water absorption up to $10 \mathrm{kGy}$ may be due to unmasking of non-polar protein residues as a result of irradiation-induced denaturation (Urbain, 1986). Increased hydrophobicity due to irradiation exposure of previously buried non-polar protein sites has also been reported for red kidney bean proteins at $2 \mathrm{kGy}$ (Dogbevi et al., 1999). This also conformed with the study of Abu et al., 2005 who reported that irradiation at $10 \mathrm{kGy}$ significantly $(\mathrm{p}<0.05)$ increased oil absorption capacity values in both cowpea flours and paste.

Water absorption capacity is an index of the amount of water retained within protein matrix. Increased irradiation dose (5kGy and 10kGy) decreased water absorption capacity but the decrease was not significantly different from the value of the raw sample $(\mathrm{p}>0.05)$. The results indicate that irradiation had no apparent effect on water absorption capacity. These findings were in accordance with those reported by Zayas (1997) and Azim et al. (2009) that the water holding capacity was not affected by gamma irradiation. Cooking and combined treatment reduced water absorption capacity from $0.84 \mathrm{ml} / \mathrm{g}$ to $0.72 \mathrm{ml} / \mathrm{g}$ and $0.73 \mathrm{ml} / \mathrm{g}$ respectively. The reduction of water absorption capacity by both treatments could be as a result hydrothermal treatment which blocked the tissue pores, thereby hindering water sippage and retention. Cooking has also been shown to reduce water absorption capacity in conophor nut (Enujiugha, 2003).

Irradiation treatment at $5 \mathrm{kGy}$ and $10 \mathrm{kGy}$ did not change the least gelation concentration of the Pentaclethra macrophylla. The gel forming ability is reported to be influenced by the nature of the protein, starch and gums in the sample as well as their interaction during heat treatment (Enujiugha et al., 2003). Cooking and combined treatment improved the binding properties of Pentaclethra macrophylla.

Foaming capacity is dependent on the protein, and the raw seed flour with the highest protein content demonstrated the highest foaming capacity. Foaming capacity was significantly reduced by cooking and combined treatment $(\mathrm{p}<0.05)$. This could be as a result of protein denaturation as well as dimunition protein solubility during heat treatment (Tagodoe \& Nip, 1994). Increased irradiation dose to $10 \mathrm{kGy}$ didn't affect foaming capacity and this did not conform to the findings of Abu et al. (2005) who reported that irradiation at 10 $\mathrm{kGy}$ decreased the foaming capacity of cowpea flours significantly $(\mathrm{p}<0.05)$. It has been suggested that foaming properties are negatively related to protein denaturation in that native proteins have higher foaming abilities than denatured proteins (Yasumatsu et al., 1972). Although higher protein denaturation would have been expected if $10 \mathrm{kGy}$ irradiation was done after Pentaclethra macrophylla seeds were cooked given the additional radiolytic effect of added water. The foaming capacity of combined treated sample $(5 \%)$ didn't reduced more than the cooked samples $(5 \%)(\mathrm{p}>0.05)$.

The foams from cooked seed and combined treated seed flours showed no stability after $30 \mathrm{~min}$, while the raw seed flour, 5 and $10 \mathrm{kGy}$ irradiated seed flour gave foam that was stable at $2 \mathrm{~h}$, indicating that the native protein gives higher stability than denatured protein (Enujiugha \& Akanbi, 2005). Similar observations had been reported for taro flour, tannia flour, cowpea flour and winged bean flour (Fagbemi \& Olaofe, 2000; Narayana \& Narasinga Rao, 1984; Bencini, 1986).

Emulsion capacity denotes the maximum amount of oil that can be emulsified by protein dispersion. The high emulsion capacity could be as a result of high content of free fatty acid which leads to increased oil absorption (Ihekoronye \& Ngoddy, 1985). Cooking and combined treatment increased emulsion capacity of Pentaclthra macrophylla. Irradiation at $5 \mathrm{kGy}$ and $10 \mathrm{kGy}$ decreased the emulsion capacity significantly $(\mathrm{p}<0.05)$. The decrease in emulsion property may be attributed to protein aggregation as well as surface hydrophobicity and change the characteristics, which affect emulsifying properties in different ways (Cheftel et al., 1985). Irradiation at 2, 10 and $50 \mathrm{kGy}$ caused significant $(\mathrm{p}<0.05)$ decrease in emulsion capacity of cowpea flours and pastes when compared with the non-irradiated (control) samples. Also, it was reported that irradiation of cowpea at 2.0 KGy caused decrease in emulsion capacity (Abu et al., 2005).

\subsection{Effect of processing on anti-nutritional factors}

The levels of some anti-nutritional factors in the raw and processed seed flour samples are presented in Table 4. The anti-nutritional factors are generally reported to have the capacity of retarding growth and lowering digestibility and absorption of important dietary nutrients. 
Each successive processing step significantly $(\mathrm{p}<0.05)$ lowered the concentrations of oxalate and tannin in the Pentaclethra seeds. Oxalic acid and its salts can have deleterious effects on human nutrition and health, particularly by decreasing calcium absorption and aiding the formation of kidney stones (Noonan and Savage, 1999). High-oxalate diets can increase the risk of renal calcium oxalate formation in certain groups of people (Libert and Franceschi, 1987). The majority of urinary stones formed in humans are calcium oxalates stones (Hodgkinson, 1977). The oxalate content was recorded lowest $(1.3 \mathrm{mg} / \mathrm{g})$ for the combined treated sample and highest $(2.54 \mathrm{mg} / \mathrm{g})$ for the raw seed. Cooking treatments were found effective measure to reduce the oxalate content in these wild tubers. Cooking may cause considerable skin rupture and facilitate the leakage of soluble oxalate into cooking water (Albihn and Savage, 2001), this may be the possible reason to observed high reduction in oxalate level upon cooking. The reduction in oxalate levels on cooking is expected to enhance the bioavailability of essential dietary minerals of the African oil bean, as well as reduce the risk of kidney stones occurring among consumers.

Phytic acid chelates mineral cations and proteins, forming insoluble complexes, which leads to reduced bioavailability of trace minerals and reduced digestibility of proteins (Reyden \& Selvendran, 1993). According to Hurrell et al. (1992), phytic acid inhibits iron absorption, which invariably contributes to the high prevalence of iron deficiency in infants in developing countries. The reduction in phytate level could be interpreted as the main reason behind the observed increase in the concentrations of some of the minerals during cooking. It has been suggested that the traditional methods employed in processing the seeds, namely hydrothermal treatment, soaking and fermentation, could considerably reduce the levels of the anti-nutritional factors (Enujiugha \& Ayodele-Oni, 2003). Also, the apparent decrease in phytate content during cooking may be partly due either to the formation of insoluble complexes between phytate and other components, such as phytate-protein and phytate-protein-mineral complexes or to the inositol hexaphosphate hydrolyzed to penta- and tetraphosphates (Siddhuraju and Becker, 2001). The observations are contrast to Wanasundera and Ravindran, (1992) who reported that phytate content in yam tubers were unaffected by the cooking. However, cooking has been reported to lower the phytate levels in several plant foodstuffs (Badifu, 2001; Reddy et al., 1982; Saikia et al., 1999; Vijayakumari et al., 1997).

Cooking and irradiation at $10 \mathrm{kGy}$ also lead to a significant decrease in phytate level $(\mathrm{P}<0.05)$ but this was insignificant compared to $10 \mathrm{kGy}$ irradiation $(\mathrm{p}>0.05)$ but the $10 \mathrm{kGy}$ treatment lead to a significant decrease from that of the raw oil bean seed which had a value of 2.27. Cooking and irradiation caused a significant decrease (40\%) in sorghum porridge (Duodu et al., 1999). Similarly, treatment of soybean seeds with irradiation, alone or in combination with soaking, reduces the level of phytate compared to controls (Sattar et al., 1990). This reduction is probably due to chemical degradation of phytate to the lower inositol phosphates and inositol by the action of free radicals produced by the radiation (De Boland et al., 1975. View Record in ScopusCited By in Scopus (95) De Boland et al., 1975). Another possible mode of phytate loss during irradiation could have been through cleavage of the phytate ring itself.

\subsection{Rancidity indices of the oil of pentaclethra macrophylla}

The rancidity indices comprises of peroxide and iodine value, acid value as well as the free fatty acids content, as these are reflectives of oxidative (oxygen-enhanced) rancidity, total acidity and hydrolytic rancidity respectively. The products of rancidity are known to be hazardous to health since they are associated with aging, membrane damage, heart disease and cancer (Cosgrove et al., 1987). The rancidity indices of oil as affected by processing are presented in Table 5 .

Free fatty acids content is an indicator of the level of hydrolytic rancidity of oil. The free fatty acid of Pentaclethra macrophylla oil sample reduced significantly upon cooking ( $\mathrm{p}<0.05)$ from 5.22 to 4.43 (\% FFA as oleic acid). This may be due to the loss of volatile free fatty acid leading to decreased free fatty acid content, alternatively the higher free fatty acid content in raw samples when compared to cooked samples could also be explained by the deactivation of enzymes, due to the heating process which would prevent the release of free fatty acids due to lipase activity in the cooked samples. These results are in agreement with those of Al-Saghir et al., (2004). View Record in Scopus Cited By in Scopus (26) Al-Saghir et al. (2004), who observed a decrease of free fatty acid in Salmon fillets, steamed or pan-fried, either with or without different types of oil. (Chantachum et al., 2000) also observed a lower free fatty acid content in oil prepared from tuna heads, by heating at $95{ }^{\circ} \mathrm{C}$, when compared to the raw oil. All treatment significantly decreased $(\mathrm{p}<0.05)$ decreased free fatty acid content and this indicate that all the oil samples other than oil from raw seed sample thus processed oil samples have fairly low acidity, and thus are in a high state of purity according to Akpuaka and Nwankwor (2000). 
In the tropics, where vegetable oils are the most common dietary lipid, it has been shown that it is desirable to ensure that the free fatty acid content of cooking oil lies within limits of $0.0-3.0 \%$ (Bassir, 1971). In the present study only the sample irradiated at $10 \mathrm{kGy}$ had values within this range. The presence of high free fatty acid content leads to the formation of off flavour, depressed smoke point of cooking and frying fat, it leads to the loss of nutritive value, undesirable toughening, increased fat absorption and reduced water absorption (Ihekoronye \& Ngoddy, 1985). Free fatty acid is usually removed during the refining process.

The acid values of the extracted oils indicate the total acidity as contributed by the fatty acids in the sample. Hydrolysis of glycerides to yield fatty acid occurs during storage.

The total acidity expressed as acid value was highest in the oil of raw sample $(18.51 \mathrm{mg} \mathrm{NaOH} / \mathrm{g})$ followed by oil from the $10 \mathrm{kGy}$ irradiated sample $(15.70 \mathrm{mg} \mathrm{NaOH} / \mathrm{g}$ of oil) and was lowest in the oil from cooked sample (8.48 $\mathrm{mg} \mathrm{NaOH} / \mathrm{g}$ ). The oil from the cooked sample would be most suitable for use in industrial manufacture of soap because it has the lowest acid value (Devine \& Williams, 1961).

The peroxide value is an indicator of deterioration of fats. As oxidation takes place the double bonds in the unsaturated fatty acids are attacked forming peroxides. Fresh oils have been shown to have peroxide values lower than $10 \mathrm{mg} / \mathrm{g}$ oil and oils become rancid when the peroxide value ranges from 20.0 to $40.0 \mathrm{mg} / \mathrm{g}$ oil (Pearson, 1976). Ojeh (1981) reported that oils with high peroxide values are unstable and easily become rancid (having a disagreeable odour). The lower peroxide value recorded for oil from the raw sample $(7.03 \mathrm{mg} / \mathrm{g}$ oil) compared to the other samples is an indication of its relative stability to oxidative rancidity. There was a significant increase $(\mathrm{p}<0.05)$ in the value of oil from cooked and 10kGy irradiated sample and it was statistically different from the value of the oil from the cooked sample and the 10kGy irradiated sample which had $10.23 \mathrm{mg} / \mathrm{g}$ oil and $8.75 \mathrm{mg} / \mathrm{g}$ oil respectively. The peroxide value of the oil from the cooked Pentaclethra macrophylla could be as a result of the heat treatment because high temperature accelerates oxidative rancidity (Ihekoronye \& Ngoddy, 1985). Exited ions produced as a result of irradiation could have lead to the formation of free radicals which could have resulted in increased peroxide value in the oil of the 10kGy irradiated sample.

The oil from the raw seed and the 10kGy irradiated seed is stable but that from the raw sample is more stable. The increased that accompanied the combined treatment may be due to the combination of the effect of excited ions formed by irradiation and the heat treatment in form of cooking. However, the high peroxide value of oil from combined treatment this indicates an increase the susceptibility of the oil to lipid oxidation.

Iodine value is the measure of the proportion of unsaturated acids present. The principle of iodine value is due to the reactivity of double bonds with halogens. The oil with high iodine value has high degree of unsaturation. The level of unsaturation decreases with oxidation. The iodine value ranged from $18.74 \mathrm{mg} / \mathrm{g}$ oil in raw sample to $17.58 \mathrm{mg} / \mathrm{g}$ oil in $10 \mathrm{kGy}$ irradiated sample, to $13.31 \mathrm{mg} / \mathrm{g}$ oil in cooked sample to $8.86 \mathrm{mg} / \mathrm{g}$ oil in combined treated sample. All the values were statistically different at $\mathrm{p}<0.05$. The reduction in the iodine value of the cooked sample could be as a result of thermal inhibition of lipase which occurs at $80^{\circ} \mathrm{C}$ (Ihekoronye \& Ngoddy, 1985). The oil from the raw oil bean had the highest iodine value and the oil obtained from the combined treated sample has the lowest.

Because there are a wide number of unsaturated acid which could be present in fats, iodine value alone does not provide a measure of specific unsaturated acid and a development of a more reliable method is required to determine fatty acid composition (Ihekoronye \& Ngoddy, 1985).

\section{Conclusion}

The results of the present study have shown that neither 5kGy nor 10kGy doses had significant effect on protein, carbohydrate, fat, ash, fibre, moisture content and energy value of Pentaclethra macrophylla seed. Increasing the dose led to nutrient retention of the seed. Changes were observed in the combined $\gamma$-irradiated and cooked sample as a result of cooking and the sample had the highest energy value. Cooking and $5 \mathrm{kGy}$ irradiation increased zinc, phosphorus and iron. Increased dose of irradiation from $5 \mathrm{kGy}$ to $10 \mathrm{kGy}$ decreased all the minerals present. Combined treatment led to the retention of sodium, calcium, zinc and iron but the same process reduced magnesium and phosphorus. The 10kGy irradiation had a negative effect on the mineral content of $\mathrm{P}$. macrophylla seeds. Gamma-irradiation and cooking increased the ability of protein in P. macrophylla to form a structure matrix for holding water, sugar and flavour and other food ingredients, and its ability to form an emulsion. Combined treatment reduced the amount of water retained in the protein matrix and this reduced its tendency as a thickening agent and its ability to form stable foam. The reduction of all the antinutritional factors by combined $\gamma$-irradiation and cooking increased nutrient bioavailability and protein digestibility as these antinutritional factors are known to bind protein and other nutrients. 


\section{References}

Abu, J. O., Klaus. M., Kwaku, G. D., Duodu, G., \& Amanda, M. (2005). Functional properties of cowpea (Vigna unguiculata L. Walp) flours and pastes as affected by gamma-irradiation. Journal of Food Chemistry, 93, 103-111. http://dx.doi.org/10.1016/j.foodchem.2004.09.010

Achinewhu, S. C. (1982). Composition and food potential of African oil bean seed (Pentaclethra macrophylla) and velvet beans (Mucuna urines). Journal of Food science, 47, 1736. http://dx.doi.org/10.1111/j.1365-2621.1982.tb05025.x

Akpuaka, M. U., \& Nwankwor, E. (2000). Extraction, analysis and utilization of a drying oil from

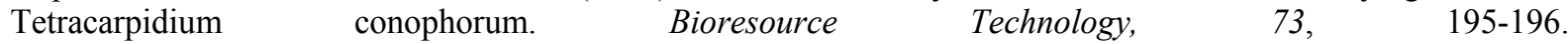
http://dx.doi.org/10.1016/S0960-8524(99)00159-5

Albihn, P. B. E., \& Savage, G. P. (2001). The effect of cooking on the location and concentration of oxalate in three cultivars of New Zealand-grown Oxalis tuberose. Journal of the Science of Food and Agriculture, 81, 1027-1033. http://dx.doi.org/10.1002/jsfa.890

Al-Saghir, S., Thurner, K., Wagner, K. H, Frisch., G., \& Luf, W. (2004). Effects of different cooking procedures on lipid quality and cholesterol oxidation of farmed salmon fish (Salmo salar). Journal of Agricultural and Food Chemistry, 52, 5290-5296. http://dx.doi.org/10.1021/jf0495946

AOAC. (1990). Official Methods of Analysis, 15th Ed. Association of Official Analytical Chemists, Washington DC.

Azim, A. M., Nour, S. E., \& Ahmed, G. O. (2009). Effect of Gamma Irradiation on Physico-chemical Characterstics of Groundnut (Arachis Hypogaea). Australian Journal of Basic and Applied Science, 3(3), 2856-2860.

Aziz, N. H., \& Mahrous, S. R. (2004). Effects of gamma irradiation on aflatoxin B1 production by Aspergillus flavus and chemical composition of three crop seeds. Nahrung, 48, 234-238. http://dx.doi.org/10.1002/food.200300429

Badifu, G. I. O. (2001). Effect of processing on proximate composition, antinutritional and toxic contents of kernels from Cucurbitaceae species grown in Nigeria. Journal of Food Composition and Analysis, 14, 153-166. http://dx.doi.org/10.1006/jfca.2000.0964

Balogun, A. M., \& Fetuga, B. L. (1980). Tannin, phytin and Oxalate content of some wild under-utilized crop-seeds in Nigeria. Food Chemistry, 30, 37-43. http://dx.doi.org/10.1016/0308-8146(88)90022-2

Bassir, O. (1971). Handbook of practical biochemistry (2nd ed.). Ibadan, Nigeria: Ibadan University Press.

Bencini, M. C. (1986). Functional properties of drumdried chick pea flour. Journal of Food Science, 1521-1526.

Burns, R. (1971). Method for estimation of tannin in grain sorghum. Agronomy Journal, 63, 511-512. http://dx.doi.org/10.2134/agronj1971.00021962006300030050x

Cambell-Platt, G., \& Grandson, A. S. (1990). Food irradiation and combination processes. Int. J. Radiat. Appl. Instum, 35, 237.

Carmody, R. N., \& Wrangham, R. W. (2009). The energetic significance of cooking. Journal of food chemistry, 57(4), 379-391.

Chantachum, S., Benjakul, S., \& Sriwirat, N. (2000). Separation and quality of fish oil from precooked and non-precooked tuna heads. Food Chemistry, 69, 289-294. http://dx.doi.org/10.1016/S0308-8146(99)00266-6

Cheftel, J. C., Cuq, J. L., \& Lorient, D. (1985). Food Chemistry (2nded.), Marcel Dekker, New York.

Coffmann, C. N., \& Garcia, V. A. (1977). Functional properties of the protein isolate from mung bean flour. Journal of Food Science, 12, 473-478.

Cosgrove, J. P., Church, D. F., \& Pryor, W. A. (1987). The kinetics of the autoxidation of polyunsaturated fatty acids. Lipids, 22, 299-304. http://dx.doi.org/10.1007/BF02533996

De Boland, A. R., Garner, G. B., \& O’Dell, B. L. (1975). Identification and properties of 'phytate' in cereal grains and oilseed products. Journal of Agricultural and Food Chemistry, 23, 1186-1189. http://dx.doi.org/10.1021/jf60202a038

Devine, J., \& Williams, P. N. (1961). The chemistry and technology of edible oils and fats (1st ed.). London: Pergamon Press. 
Dogbevi, M. K., Vachon, C., \& Lacroix, M. (1999). Physico-chemical properties of dry red kidney bean proteins and natural microflora as affected by gamma irradiation. Journal of Food Science, 64, 540-542. http://dx.doi.org/10.1111/j.1365-2621.1999.tb15080.x

Duodu, K. G., Minnaar, A., \& Taylor, J. R. N. (1999). Effect of cooking and irradiation on the labile vitamins and antinutrient content of a traditional African sorghum porridge and spinach relish. Food Chemistry, 66, 21-27. http://dx.doi.org/10.1016/S0308-8146(98)00070-3

El-Niely, H. F. G. (1996). Chemical constituents and digestibility of broad beans subjected to irradiation treatment. MSc thesis, Women's College, Ain Shams University, Cairo, Egypt.

Enujiugha, V. N. (2003). Chemical and Functional Characteristics of Conophor Nut. Pakistan Journal of Nutrition, 2(6), 335-338. http://dx.doi.org/10.3923/pjn.2003.335.338

Enujiugha, V. N. (2008). Pentaclethra macrophylla African oil bean, pp. 398-400. In: The Encyclopedia of Fruit and Nuts (J. Janick and R. E. Paull, eds.), CAB International, Oxfordshire, UK.

Enujiugha, V. N., \& Agbede, J. O. (2000). Nutritional and antinutritional characteristics of African oil beans (Pentaclethra macrophylla Benth) seeds. Applied Tropical Agriculture, 5, 11-14.

Enujiugha, V. N., \& Akanbi, C. T. (2002). Adaptable techniques for the post harvest processing and preservation of African oil bean seeds proceedings, Regional Workshop On Promotion of Appropriate Agro-processing Technologies in West Africa, Ile-Ife, Nigeria (23rd -26thOctober, 2002), 164-169.

Enujiugha, V. N., \& Akanbi, C. T. (2005). Compositional changes in African oil bean seeds during thermal processing. Pakistan Journal of Nutrition, 4(1), 27-31. http://dx.doi.org/10.3923/pjn.2005.27.31

Enujiugha, V. N., \& Ayodele-Oni, O. (2003). Evaluation of nutrient and some antinutrient in lesser-known, underutilized oil seeds. International Journal of Food Science and Technology, 38, 525-528. http://dx.doi.org/10.1046/j.1365-2621.2003.00698.x

Enujiugha, V. N., Badejo, A. A., Iyiola, S. O., \& Oluwamukomi, M. O. (2003). Effect of germination on the nutritional and functional properties of African oil bean (Pentaclethra macrophylla Benth) seed flour. Journal of Food, Agriculture and Environment, 1(3/4), 72-75.

Enujiugha, V. N., \& Olagundoye, T. V. (2001). Comparative nutritional characteristics of raw, fermented and roasted African oil bean (Pentaclethra macrophylla Benth) seeds. La Rivista Italiana delle Sostanze Grasse, 78(4), 247-250.

Fagbemi, T. N., \& Olaofe, O. (2000). The chemical composition and functional properties of raw and precooked taro (Colocasia esculenta) flours. Journal of Food Chemistry.

Farag, M. E. (1989). Radiation deactivation of antinutritional factors: trypsin inhibitor and hemagglutinin in soybeans. Egyptian Journal of Radiation Sciences and Applications, 6, 207-215.

Farkas, J. (1990). Combination of irradiation with mild heat treatment. Food control, 1, 223-229. http://dx.doi.org/10.1016/0956-7135(90)90073-L

Gilfillan, E. S., \& Linden, L. (1955). Effects of nuclear radiation on the strength of yearns. Textile Research Journal, 25, 773-777. http://dx.doi.org/10.1177/004051755502500905

Grant, I. R., \& Patterson, M. F. (1995). Combined effect of gamma radiation and heating on the destruction of Listeria monocytogenesis and Salmonella typhirium in cook chill roast beef and gravy. International Journal of Food Microbiology, 27, 117-128. http://dx.doi.org/10.1016/0168-1605(94)00156-Z

Hodgkinson, A., (1977). Oxalic acid in Biology and Medicine. London, Academic Press.

Hurrel, R. F., Juillert, M. A., Reddy, M. B., Lynch, S. R., Dassenko, S. A., \& Cook, J. D. (1992). Soy protein, phytate and iron absorption in humans. American Journal of Clinical Nutrition, 56, 573-578.

Ige, M. M., Ogunsua, A. O., \& Oke, O. L. (1984). Functional Properties of the Proteins of Some Nigerian Oilseeds, Conophor Seeds and Three Varieties of Melon Seeds. Journal of Agricultural and Food Chemistry, 32, 822-825. http://dx.doi.org/10.1021/jf00124a031

Ihenkoronye, A. I., \& Ngoddy, P. O. (1985). Integrated Food Science and Techology for the Tropics. Macmillian publishers, London, pp. 17-18, 45, 53, 64, 66.

Jerome, F. A., Millett, M. A., \& Lawton, E. (1952). Effect of high energy cathode rays on cellulose. Industrial and Engineering Chemistry, 44, 2848-2852. http://dx.doi.org/10.1021/ie50516a027 
Josephson, E. S., Thomas, M. H., \& Calhoun, W. K. (1978). Nutritional aspects of food irradiation; an overview. Journal of Food Processing and Preservation, 2, 299-313. http://dx.doi.org/10.1111/j.1745-4549.1978.tb00564.x

Kashani, G. G. \& Valadon, L. R. G. (1984). Effects of gamma irradiation on the lipids, carbohydrates and proteins of Iranian pistachio kernels. Journal of Food Technology, 19, 631-638. http://dx.doi.org/10.1111/j.1365-2621.1984.tb01880.x

Kingsley, M. O. (1995). Effect of processing some antinutritive and toxic component on the nutritional composition of African oil bean seed (Penthaclethra macrophylla Benth). Journal of Food Science and Agriculture, 68, 153-158. http://dx.doi.org/10.1002/jsfa.2740680204

Kinsella, J. E. (1976). Functional properties of proteins in foods: a survey. Critical Reviews in Food Science and Nutrition, 1 (3), 219-280.

Libert, B., \& Franceschi, V. R. (1987). Oxalate in crop plants. Journal of Agricultural and Food Chemistry, 35(6), 926-937. http://dx.doi.org/10.1021/jf00078a019

Mepba, H. D., Eboh, L., \& Banigo, D. E. B. (2007). Effects of processingtreatments on the nutritive composition and consumer acceptance of some Nigerian edible leafy vegetables. Afr. J. Food Agric. Nutr. Dev., 7(1), 1-18.

Molins, M. (2001). Food Irradiation: Principles and Applications, Wiley Publication, USA.

Narayana, K., Narasinga Rao, M. S. (1984). Effect of partial proteolysis on the functional properties of winged bean (Psophocarpus tetragolobus) flour. Journal of Food Science, 49, 944-947. http://dx.doi.org/10.1111/j.1365-2621.1984.tb13247.x

Noonan, S. C., \& Savage, G. P. (1999). Oxalic acid and its effects on humans. Asia Pacific Journal of Clinical Nutrition, 8, 64-74. http://dx.doi.org/10.1046/j.1440-6047.1999.00038.x

Ojeh, O. (1981). Effects of refining on the physical and chemical properties of cashew kernel oil. Journal of Fats and Oils Technology, 16, 513-517.

Osman, E. N. (1967). Starch in food industry. In: Whistler, R.L. and Paschall, E.F.,Editors, Starch: chemistry and technology (vol. 2), Academic Press, London.

Price, M. L., Scoyoc, S. V., \& Butler, L. G. (1978). A critical evaluation of the vanillin reaction as an assay for tannin in sorghum grain. Journal of Agricultural and Food Chemistry, 26, 1214-1218. http://dx.doi.org/10.1021/jf60219a031

Prinyawiwatkul, W., Beuchat, L. R., McWatters, K. H., \& Phillips, R. D. (1997). Functional properties of cowpea (Vigna unguiculata) flour as affected by soaking, boiling, and fungal fermentation. Journal of Agricultural and Food Chemistry, 45(2), 480-486. http://dx.doi.org/10.1021/jf9603691

Rady, A. H., Abdel Hady, S. M., Elnashabi F. M., Afifi, E. A., \& Salam, E. M. (2002). Influence of Gamma rays and Microwave heating on the Quality of Olive fruits and their virgin oil. Isotope and Rad. Res, 34, 369-380.

Reddy, N. R., Sathe, S. K., \& Salunkhe, D. K. (1982). Phytate in legumes and cereals. Advances in Food Research, 28, p. 1. http://dx.doi.org/10.1016/S0065-2628(08)60110-X

Reyden, P., \& Selvendran, R. R. (1993). Phytic acid: properties and determination. In: R. Macrae, R. K. Robinson and M.J. Sadler, Editors, Encyclopedia of food science, food technology and nutrition, Academic Press, London, pp. 3582-3587.

Saikia, P., Sarkar, C. R., \& Borua, I., (1999).Chemical composition, antinutritional factors and effect of cooking on nutritional quality of rice bean Virgna umbellate. Journal of Food Chemsitry, 67, 347-352. http://dx.doi.org/10.1016/S0308-8146(98)00206-4

Satter, A., \& Neelofar Akhtar, M. A. (1990). Irradiation and germination effects on phytate, protein and amino acids of soybean. Plant Foods for Human Nutrition, 40, 185-195. http://dx.doi.org/10.1007/BF01104141

Siddhuraju, P., \& Becker, K. (2001). Effect of various domestic processing methods on antinutrients and in vitro-protein and starch digestibility of two indigenous varieties of Indian pulses, Mucuna pruriens var utilis. Journal of Agricultural and Food Chemistry, 49(6), 3058-3067. http://dx.doi.org/10.1021/jf001453q

Steel, R. G. D., \& Torrie, J. H. (1980). Principles and procedures of statistics: A biometrical approach, 2 nd ed. McGraw-Hill Inc., New York

Stevenson, M. H. (1994). Identification of Irradiated foods. Food Technology, 48, 141-144.

Tagodoe, A., \& Nip, N. W. (1994). Functional properties of raw and precooked taro flour. International Journal of Food Science and Technology, 29, 457-462. http://dx.doi.org/10.1111/j.1365-2621.1994.tb02087.x 
Tester, R. F., \& Sommerville, M. D. (2000). Swelling and enzymatic hydrolysis of starch in low water systems. $J$. Cereal Sci., 33, 193-203. http://dx.doi.org/10.1006/jcrs.2000.0350

Underwood, B. A. (2003). Scientific research: essential, but is it enough to combat world food insecurities? Journal of Nutrition, 133(Suppl. 1), 1434S-1437S.

Urbain, W. M. (1986). Food irradiation, Academic press, London.

Vijayakumari, K., Siddhuraju, P., \& Janardhanan, K. (1997). Effect of domestic processing on the levels of certain antinutrients in Prosopis Chilensis (Molina) Stunz. Seeds. Food Chemistry, 59 (3), 367-371. http://dx.doi.org/10.1016/S0308-8146(96)00249-X

Wanasundera, J. P. D., \& Ravindran, G. (1992). Effects of cooking on the nutrient and antinutrient contents of yam tubers (Dioscorea alata and Dioscorea esculenta). Food Chemistry, 45, 247-250. http://dx.doi.org/10.1016/0308-8146(92)90155-U

Wheeler, E. L., \& Ferrel, R. E. (1971). A method for phytic acid determination in wheat fractions. Cereal Chemistry, 48, 312-316.

Yasumatsu, K. K., Sawada, S., Moritaka, M., Misaki, J., Toda, T., Wada, T., \& Ishii, K. (1972). Whipping and emulsifying properties of soybean products. Journal of Agricultural and Biological Chemistry, 36, 719. http://dx.doi.org/10.1271/bbb1961.36.719

Zayas, J. F. (1997). Functionality of proteins in food. New York:Springer-Verlag, pp. 1, 34-56, 144-146. http://dx.doi.org/10.1007/978-3-642-59116-7_1

Table 1. Proximatecomposition of raw and processed pentaclethra macrophylla seeds ( $\% 100 \mathrm{~g}$ dry weight)

\begin{tabular}{llllll}
\hline Parameters & Raw & Cooked & $\begin{array}{l}\text { 5kgy } \\
\text { Irradiated }\end{array}$ & $\begin{array}{l}\text { 10kgy } \\
\text { Irradiated }\end{array}$ & $\begin{array}{l}\text { 10kgy } \\
\text { Irradiated And } \\
\text { Cooked }\end{array}$ \\
\hline Protein & $32.91 \mathrm{a} \pm 0.08$ & $31.31 \mathrm{~b} \pm 0.31$ & $32.50 \mathrm{a} \pm 0.07$ & $32.66 \mathrm{a} \pm 0.16$ & $30.55 \mathrm{c} \pm 0.71$ \\
Fat & $47.43 \mathrm{c} \pm 0.10$ & $50.39 \mathrm{~b} \pm 0.42$ & $48.07 \mathrm{c} \pm 0.31$ & $47.42 \mathrm{c} \pm 0.50$ & $51.19 \mathrm{a} \pm 0.30$ \\
Ash & $2.91 \mathrm{a} \pm 0.06$ & $2.25 \mathrm{~b} \pm 0.47$ & $2.79 \mathrm{a} \pm 0.01$ & $2.76 \mathrm{a} \pm 0.25$ & $2.28 \mathrm{~b} \pm 0.27$ \\
Fibre & $2.22 \mathrm{c} \pm 0.15$ & $3.27 \mathrm{a} \pm 0.01$ & $2.41 \mathrm{c} \pm 0.09$ & $2.20 \mathrm{c} \pm 0.17$ & $2.73 \mathrm{~b} \pm 0.55$ \\
Nfe & $14.54 \mathrm{a} \pm 0.24$ & $12.96 \mathrm{~b} \pm 0.10$ & $14.23 \mathrm{a} \pm 0.28$ & $14.69 \mathrm{a} \pm 0.23$ & $12.71 \mathrm{~b} \pm 0.21$ \\
Mc & $4.15 \mathrm{c} \pm 0.72$ & $9.36 \mathrm{~b} \pm 0.42$ & $4.66 \mathrm{c} \pm 0.33$ & $4.75 \mathrm{c} \pm 0.28$ & $10.42 \mathrm{a} \pm 0.62$ \\
E Value $(\mathrm{Kj})$ & $2583.81 \mathrm{~b} \pm 1.49$ & $2643.60 \mathrm{a} \pm 9.58$ & $2595.37 \mathrm{~b} \pm 7.65$ & $2579.61 \mathrm{~b} \pm 17.67$ & $2655.27 \mathrm{a} \pm 2.81$ \\
\hline
\end{tabular}

*All values are expressed as means of triplicate determinations (mean \pm s.d.). Values along same row with the same following letters in superscript are not significantly different $(\mathrm{p}>0.05)$.

Table 2. Mineral composition of raw and processed pentaclethra macrophylla seeds $(\mathrm{mg} / 100 \mathrm{~g})$

\begin{tabular}{lllllll}
\hline Parameters & Raw & cooked & $\begin{array}{l}5 \\
\text { irradiated }\end{array}$ & $\begin{array}{l}\text { kgy } \\
\text { irradiated }\end{array}$ & $\begin{array}{l}\text { 10kgy irradiated } \\
\text { and cooked }\end{array}$ \\
\hline Pottasium & $4.38 \mathrm{a} \pm 0.51$ & $1.85 \mathrm{~b} \pm 0.06$ & $1.62 \mathrm{c} \pm 0.09$ & $0.92 \mathrm{~d} \pm 0.01$ & $1.29 \mathrm{dc} \pm 0.10$ \\
Sodium & $0.26 \mathrm{c} \pm 0.03$ & $0.37 \mathrm{c} \pm 0.02$ & $1.56 \mathrm{a} \pm 0.03$ & $0.91 \mathrm{~b} \pm 0.00$ & $0.30 \mathrm{c} \pm 0.19$ \\
Calcium & $2.61 \mathrm{~b} \pm 0.30$ & $3.53 \mathrm{a} \pm 0.10$ & $3.59 \mathrm{a} \pm 0.20$ & $1.79 \mathrm{c} \pm 0.58$ & $2.45 \mathrm{~b} \pm 0.21$ \\
Zinc & $0.30 \mathrm{~b} \pm 0.03$ & $0.45 \mathrm{a} \pm 0.04$ & $0.47 \mathrm{a} \pm 0.02$ & $0.25 \mathrm{c} \pm 0.01$ & $0.33 \mathrm{~b} \pm 0.00$ \\
Iron & $0.24 \mathrm{bc} \pm 0.91$ & $0.36 \mathrm{a} \pm 0.08$ & $0.28 \mathrm{~b} \pm 0.01$ & $0.17 \mathrm{c} \pm 0.03$ & $0.23 \mathrm{bc} \pm 0.09$ \\
Magnesium & $0.52 \mathrm{a} \pm 0.04$ & $0.56 \mathrm{a} \pm 0.03$ & $0.59 \mathrm{a} \pm 0.02$ & $0.28 \mathrm{c} \pm 0.01$ & $0.47 \mathrm{~b} \pm 0.10$ \\
Phosphorus & $0.43 \mathrm{~b} \pm 0.01$ & $0.48 \mathrm{a} \pm 0.20$ & $0.48 \mathrm{a} \pm 0.01$ & $0.26 \mathrm{~d} \pm 0.22$ & $0.35 \mathrm{c} \pm 0.21$ \\
\hline
\end{tabular}

*All values are expressed as means of triplicate determinations (mean \pm s.d.). Values along same row with the same following letters in superscript are not significantly different $(\mathrm{p}>0.05) . \mathrm{Cu}$ and $\mathrm{Pb}$ were not detected in the samples. 
Table 3. Functional properties of raw and processed penthaclethra macrophylla seeds

\begin{tabular}{llllll}
\hline Parameters & Raw & Cooked & $\begin{array}{l}\text { Kkgy } \\
\text { Irradiated }\end{array}$ & $\begin{array}{l}10 \mathrm{kgy} \\
\text { Irradiated }\end{array}$ & Parameters \\
\hline $\mathrm{Oac}(\mathrm{ml} / \mathrm{g})$ & $1.27 \mathrm{~b} \pm 0.31$ & $1.00 \mathrm{~b} \pm 0.00$ & $1.39 \mathrm{a} \pm 0.12$ & $1.43 \mathrm{a} \pm 0.31$ & Oac $(\mathrm{ml} / \mathrm{g})$ \\
$\mathrm{Wac}(\mathrm{ml} / \mathrm{g})$ & $0.84 \mathrm{a} \pm 0.04$ & $0.72 \mathrm{c} \pm 0.00$ & $0.80 \mathrm{ab} \pm 0.04$ & $0.76 \mathrm{bc} \pm 0.00$ & $\mathrm{Wac}(\mathrm{ml} / \mathrm{g})$ \\
$\mathrm{Fc}(\%)$ & $13.33 \mathrm{a} \pm 2.89$ & $5.00 \mathrm{~b} \pm 0.00$ & $13.33 \mathrm{a} \pm 2.89$ & $11.67 \mathrm{a} \pm 2.89$ & $\mathrm{Fc}(\%)$ \\
$\mathrm{Lgc}(\mathrm{g} / \mathrm{cm} 3)$ & $10.33 \mathrm{~b} \pm 0.58$ & $12.33 \mathrm{a} \pm 0.58$ & $10.67 \mathrm{~b} \pm 0.58$ & $10.67 \mathrm{~b} \pm 0.58$ & $\mathrm{Lgc}(\mathrm{g} / \mathrm{cm} 3)$ \\
$\mathrm{Ec}(\%)$ & $37.50 \mathrm{~b} \pm 2.00$ & $42.00 \mathrm{a} \pm 1.00$ & $34.00 \mathrm{c} \pm 2.00$ & $35.33 \mathrm{c} \pm 1.15$ & $\mathrm{Ec}(\%)$ \\
\hline
\end{tabular}

All values are expressed as means of triplicate determinations (mean \pm s.d.) Values along same row with the same following letters in superscript are not significantly different $(\mathrm{p}>0.05)$.

Table 4. Antinutritional factors in pentaclethra macrophylla seeds

\begin{tabular}{llllll}
\hline Parameters & Raw & Cooked & 5kgy irradiated & $\begin{array}{l}\text { 10kgy } \\
\text { irradiated }\end{array}$ & $\begin{array}{l}\text { Irradiated and } \\
\text { 10kgy cooked }\end{array}$ \\
\hline Tannin $(\mathrm{g} / 100 \mathrm{~g})$ & $0.48 \mathrm{a} \pm 0.00$ & $0.34 \mathrm{~b} \pm 0.00$ & $0.37 \mathrm{~b} \pm 0.00$ & $0.32 \mathrm{c} \pm 0.02$ & $0.29 \mathrm{~d} \pm 0.01$ \\
Oxalate $(\mathrm{mg} / \mathrm{g})$ & $2.54 \mathrm{a} \pm 0.03$ & $2.11 \mathrm{bc} \pm 0.00$ & $2.14 \mathrm{~b} \pm 0.01$ & $1.94 \mathrm{c} \pm 0.20$ & $1.30 \mathrm{~d} \pm 0.10$ \\
Phytin-p $(\mathrm{g} / 100 \mathrm{~g})$ & $0.64 \mathrm{a} \pm 0.00$ & $0.63 \mathrm{a} \pm 0.05$ & $0.63 \mathrm{a} \pm 0.01$ & $0.55 \mathrm{~b} \pm 0.10$ & $0.53 \mathrm{~b} \pm 0.04$ \\
Phytate $(\mathrm{mg} / 100 \mathrm{~g})$ & $2.27 \mathrm{a} \pm 0.01$ & $2.23 \mathrm{a} \pm 0.18$ & $2.23 \mathrm{a} \pm 0.04$ & $1.94 \mathrm{~b} \pm 0.35$ & $1.87 \mathrm{~b} \pm 0.02$
\end{tabular}

* All values are expressed as means of triplicate determinations (mean \pm s.d.). Values along same row with the same following letters in superscript are not significantly different $(\mathrm{p}>0.05)$.

Table 5. Physicochemical properties of the seed oil extract

\begin{tabular}{lllll}
\hline Parameters & Raw & Cooked & $10 \mathrm{kGy}$ Irradiated & $\begin{array}{l}\text { Irradiated } \\
\text { And10kGy Cooked }\end{array}$ \\
\hline $\begin{array}{l}\text { Peroxide value } \\
(\mathrm{mg} / \mathrm{g} \text { oil) }\end{array}$ & $7.03 \mathrm{~d} \pm 0.45$ & $10.23 \mathrm{~b} \pm 0.38$ & $8.75 \mathrm{c} \pm 0.56$ & $16.50 \mathrm{a} \pm 0.53$ \\
$\begin{array}{l}\text { Iodine value } \\
(\mathrm{mg} / 100 \mathrm{~g})\end{array}$ & $18.74 \mathrm{a} \pm 0.15$ & $13.13 \mathrm{c} \pm 0.15$ & $17.58 \mathrm{~b} \pm 0.31$ & $8.86 \mathrm{~d} \pm 0.17$ \\
$\begin{array}{l}\text { Acid value } \\
(\mathrm{mg} \text { NaoH/g oil) }\end{array}$ & $18.51 \mathrm{a} \pm 2.80$ & $8.48 \mathrm{~d} \pm 0.80$ & $15.70 \mathrm{~b} \pm 0.03$ & $13.06 \mathrm{c} \pm 0.28$ \\
$\begin{array}{l}\text { Free fatty acid } \\
(\% F F A \text { as oleic) }\end{array}$ & $5.22 \mathrm{a} \pm 0.08$ & $4.43 \mathrm{~b} \pm 0.11$ & $0.24 \mathrm{~d} \pm 0.02$ & $3.69 \mathrm{c} \pm 0.08$ \\
\hline
\end{tabular}

*All values are expressed as means of triplicate determinations (mean \pm s.d.). Values along same row with the same following letters in superscript are not significantly different $(\mathrm{p}>0.05)$. 